\title{
Pengembangan Perangkat Pembelajaran Matematika dengan Pendekatan Matematika Realistik pada Pokok Bahasan Tabung untuk SMP Negeri 2 Nanga Taman Kelas IX
}

\author{
Lusius Yupinus ${ }^{1 *}$, Ichsan $^{2}$, Yadi Ardiawan ${ }^{3}$ \\ 1,2,3 IKIP PGRI Pontianak \\ *ylusius@gmail.com
}

\begin{abstract}
ABSTRAK
Tujuan dalam penelitian pengembangan ini adalah untuk mendapatkan desain pengembangan perangkat pembelajaran matematika berupa RPP dan LKS dengan pendekatan matematika realistik pada pokok bahasan tabung untuk SMP Negeri 2 Nanga Taman kelas IX. Selain itu, penelitian ini juga bertujuan untuk menguji tingkat kevalidan, kepraktisan, dan keefektifan perangkat pembelajaran dengan pendekatan matematika realistik pada pokok bahasan tabung. Penelitian ini merupakan penelitian pengembangan dengan model pengembangan 4-D yang meliputi define, design, develop, dan dissemination. Hasil penelitian menunjukkan bahwa berdasarkan penilaian ahli materi, ahli media, dan guru matematika perangkat pembelajaran yang dikembangkan memiliki kriteria sangat valid dengan rata-rata total skor 190,33 untuk RPP dan 297,5 untuk LKS. Berdasarkan pada hasil pengisian angket respon siswa dan angket respon guru dapat disimpulkan bahwa perangkat pembelajaran yang dikembangkan memiliki kriteria sangat praktis dalam penggunaannya dengan rata-rata total skor 91,1 untuk angket respon siswa dan jumlah 84 untuk angket respon guru. Sedangkan, berdasarkan pada hasil pengisian observasi keterlaksanaan pembelajaran dan hasil tes evaluasi hasil belajar dapat disimpulkan bahwa perangkat pembelajaran yang dikembangkan memiliki tingkat keefektifan yang yang sangat baik dengan persentase keterlaksanaan pembelajaran $94,87 \%$ dan persentase ketuntasan siswa $95 \%$.
\end{abstract}

Kata kunci: matematika realistik, perangkat pembeljaran, tabung.

\section{ABSTRACT}

The purpose of this research development is to obtain a design to develop mathematics learning tools in the form of RPP and LKS with a realistic mathematical approach to the subject matter of the tube for SMP 2 Nanga Taman class IX. In addition, this study also aims to test the level of validity, practicality, and effectiveness of learning tools with a realistic mathematical approach on the subject matter of the tube. This research development study with 4-D development model that includes define, design, develop, and dissemination. The result showed that based on the assessment of material experts, media experts and mathematics teacher the developed learning tools has very valid criteria with an average total score of 190,33 for RPP and 297,5 for LKS. based on the results of filling in student response questionnaires and teacher response questionnaires in can be concluded that the developed learning tools have very pactical criteria in their use with an average total score of 91,1 for student response questionnaires and a total of 84 for teacher response questionnaires. Meanwhile, based on the results of observing the observation learning and the results of the evaluation of learning outcomes, it can be concluded that the developed learning device has a very good level of effectiveness with the percentage of learning accomplishment of $94,87 \%$ and $95 \%$ of student completeness.

Keyword: realistic mathematic, learning media, tube 


\section{PENDAHULUAN}

Mata pelajaran matematika merupakan pelajaran yang pelu diberikan kepada peserta didik mulai dari Sekolah Dasar (SD) sampai Sekolah Menengah untuk membekali peserta didik dengan kemampuan berpikir logis, analitis, sistematis, dan kreatif, serta berkerjasama. Kompetensi tersebut diperlukan agar peserta didik dapat memiliki kemampuan memperoleh, mengelola, dan mendapatkan informasi untuk bertahan hidup pada keadaan yang selalu berubah, tidak pasti, dan kompetitif (Depdiknas, 2006: 416). Oleh sebab itu matematiaka merupakan mata pelajaran yang wajib dipelajari disemua jenjang pendidikan.

Kenyataan yang belum sesuai harapan, dari hasil wawancara tidak terstruktur dengan guru matematika SMP Negeri 2 Nanga Taman prestasi belajar matematika siswa masih relatif rendah. Kemampuan siswa dalam penguasaan konsep-konsep matematika sangat rendah apalagi dalam aplikasi matematika dalam kehidupan sehari-hari, siswa cenderung mengalami kebingungan pada saat diberikan masalah yang sedikit berbeda dengan contoh yang diberikan oleh guru. Hal tersebut karena masalah yang diberikan kurang berkaitan dengan kehidupan sehari-hari siswa atau kurang realistis. Salah satu kegitan awal dalan meningkatkan kualitas belajar adalah merancang perangkat pembelajaran yang mengacu pada model pengembangan agar memudahkan proses pembelajaran (Harijanto, 2007: 2). Artinya setiap guru harus dapat menfasilitasi siswa-siswinya dengan mengembangkan perangkat pembelajara yang efektif bagi siswa. Guru sebagai pendidik profesional diharapkan memiliki kemampuan mengembangkan perangkat pembelajaran dengan memperhatikan karakteristik dan lingkungan sosial siswa (Depdiknas, 2010: 25). Perangkat pembelajaran dapat berupa Rencana Pelaksanaan Pembelajaran (RPP) dan Lembar Kegiatan Siswa (LKS).

Rencana pelaksanaan pembelajaran merupakan rancangan pembelajaran mata pelajaran per unit yang akan dilaksanakan guru dalam kegiatan pembelajaran di kelas (Muclich, 2007: 45). Sedangkan lembar kegiatan siswa adalah lembar-lembar berisi tugas yang harus dikerjakan oleh peserta didik. Lembar kegiatan biasanya berupa petunjuk, langkah-langkah untuk menyelesaikan suatu tugas (Depdiknas, 2008: 127). Penggunaan LKS dalam kegiatan pembelajaran dapat mendorong siswa untuk mengolah sendiri bahan yang dipelajari atau bersama dengan teman dalam suatu bentuk diskusi kelompok. Penggunaan LKS juga dapat memberi peluang bagi siswa untuk megembangkan kreativitasnya, walaupaun masih ada peranan guru dalam memberikan arahan/bimbingan. Kenyataannya masih sangat terbatas jumlah LKS yang dikembangkan sendiri oleh oleh guru di Indonesia (Suhadi, 2007: 13).

Berdasarkan hasil observasi dan wawancara tidak terstruktur di SMPN 2 Nanga Taman diketahui bahwa guru masih kesulitan menemukan perangkat pembelajaran yang dapat memfasilitasi siswa dalam mengembangkan pengetahuan siswa. Selain itu, guru juga belum mengembangkan RPP dan LKS secara mandiri karena terkendala kesibukan, kurangnya referensi buku yang dimiliki sekolah. Dari hal tersebut diatas ditemukan pada RPP tidak adanya petunjuk waktu kegiatan yang menjadi petunjuk bagi guru untuk memperkirakan alokasi waktu yang digunakan pada tiap tahap kegiatan. Di samping itu ada masalah lain yang ditemukan yaitu LKS yang digunakan dalam proses belajar di kelas merupakan LKS yang berasal dari penerbit yang berisi ringkasan materi dan kumpulan soal sehingga kurang memberikan motivasi kepada siswa untuk aktif dalam pembelajaran. LKS seperti itu tidak memberikan pengalaman bagi siswa dan tidak mendorong pengembangan kemampuan berpikir siswa, sehingga diperlukannya 
pengembangan LKS. Dengan adanya LKS, pelaksanaan proses belajar mengajar akan lebih mudah bagi siswa dan guru.

Secara garis besar, matematika dapat dibagi menjadi empat cabang yaitu aritmatika, aljabar, geometri, dan analisis. Salah satu cabang dalam matematika yang bayak berkaitan dengan kehidupan sehari-hari siswa adalah geometri. Objek pembelajaran geometri meliputi titik, garis, sudut, bidang datar, dan ruang (Suwaji, 2008). Setiap benda yang berada disekitar siswa merupakan benda-benda berdimensi tiga yang menjadi objek pembelajaran dalam geometri. Geometri sudah diajarkan kepada siswa sejak jenjang sekolah dasar karena memiliki banyak manfaat. Menurut Walle (2006), geometri perlu diajarkan karena: geometri membantu siswa memiliki keyakinan yang utuh terhadap dunia nyata, geometri dapat mengantar siswa melakukan eksplorasi sehingga dapat membantu megembangkan kemampuan pemecahan masalah, geometri dapat menunjang ilmu pengetahuan lain, geometri banyak digunakan orang dalam kehidupan sehari-hari, goemetri penuh teka-teki dan menyenangkan.

Besarnya manfaat mempelajari geometri bagi siswa ternyata tidak berbanding lurus dengan prestasi yang diperoleh siswa pada materi geometri di sekolah. Berdasarkan survey yang dilakukan Progremme for International Student Assessment (PISA), siswa sekolah di Indonesia lemah dalam geometri, khususnya dalam pemahaman ruang dan bentuk (Suwaji, 2008). Geometri adalah salah satu materi matematika yang harus dikuasai oleh siswa SMP. Salah satu materi geometri dalam pelajaran matematika SMP kelas IX adalah tabung yang terdapat dalam bab bangun ruang sisi lengkung.

Materi tabung dipelajari oleh siswa SMP kelas IX yang pada umumnya berusia di atas 13 tahun. Menurut Sugihartono, dkk (2007), siswa pada usia tersebut mengalami ranah kognitif sehingga dapat berpikir secara abstrak namun masih belum maksimal sehigga proses pembelajaran masih perlu dihubungkan dengan materi-materi kongkrit. Maka dari itu, perangkat pembelajaran yang dikembangkan dalam materi tabung menghubungkan materi pembelajaran dengan masalah yang nyata agara siswa dapat memahami konsep yang berhubungan dengan masalah nyata.

Tujuan PISA adalah untuk mengetahui sejauh mana siswa bisa menerapkan pengetahuan yang sudah di pelajari disekolah dalam kehidupan sehari-hari dan dalam berbagai situasi. Dilihat dari hasil penelitian PISA tahun 2012, Indonesia hanya mampu mencapai posisi 64 dari 65 negara dengan skor 375 (OECD, 2013) sedangkan pada 3 tahun berikutnya yakni penelitian PISA tahun 2015, Indonesia berada diposisi 57 dari 65 negara dengan skor 386 (OECD, 2016). Dari hasil penelitian tersebut didapapat bahwa kemampuan matematika siswa Indonesia dari 2 tahun terakhir menunjukkan peningkatan. Jika dibandingkan dengan negara-negara lain, oleh sebab itu kemampuan matematika siswa indonesia perlu ditingkatkan. Dibutuhkan adanya inovasi dalam pembelajaran matematika, salah satunnya adalah dengan menggunkan pendekatan pembelajaran yang sejalan dengan PISA. Menurut Marpaung dan Julie (2011: 10), pedekatan pendidikan matematika realistik sejalan dengan PISA.

Pendidikan matematik realistik memiliki lima karakter pembelajaran yaitu: penggunaan konteks, penggunaan model untuk matematisai progresif, pemanfaatan hasil kontruksi siswa, iteraktif, dan keterkaitan (Wijaya, 2012: 21-23). Kelima karakter pendidikan matematika realistik tersebut sejalan dengan Permendiknas RI No 41 Tahun 2007 tentang standar proses yang mengamanatkan bahwa proses pembelajaran sebaiknya dilakukan melalui proses eksplorasi, elaborasi, dan konfirmasi. 
Menurut Wijaya (2012: 28), kegiatan eksplorasi merupakan fokus dari karakteristik pendidikan matematika realistik yang pertama, yaitu menggunakan konteks. Hasil kegiatan eksplorasi selanjutnya dikembangkan menuju penemuan dan pengembangan konsep melalui proses elaborasi. Dalam pendidikan matematika realistik konteks situasi diterjemahkan melalui matematika horizontal kemudian di elaborasi menjadi penemuan matematika formal dari konteks situasi melalui matematika formal. Proses terakhir adalah konfirmasi untuk membangun argunentasi yang menguatkan hasil eksplorasi dan elaborasi. Melalui proses konfirmasi, gagasan siswa tidak hanya dikomunikasikan ke siswa lain tetapi juga dapat dikembangkan berdasarkan tanggapan siswa lain. Karakter interaktivitas dari pendidikan matematika realistik memberikan ruang bagi siswa untuk saling berkomunikasi dalam mengembangkan strategi dan membangun konsep matematika. Oleh karena itu, bisa dikatakan bahwa pendekatan matematika realistik sejalan dengan Kurikulum Tingkat Satuan Pendidikan.

Berdasarkan uraian di atas, dirasakan perlu ada penelitian tentang "Pengembangan Perangkat Pembelajaran Matematika dengan Pendekatan Matematika Realistik pada Pokok Bahasan Tabung untuk SMP Negeri 2 Nanga Taman kelas IX”.

\section{METODE PENELITIAN}

Jenis penelitian ini adalah penelitian dan pengembangan (Research and Development atau $R \& D$ ). Menurut Sugiyono (2012: 407), "Penelitian dan pengembangan (Research and Development/R\&D) adalah metode penelitian yang digunakan untuk menghasilkan produk tertentu, dan menguji keefektifan produk tersebut".

\subsection{Subjek Pengembangan}

Subjek pengembangan dalam penelitian ini adalah validator, dimana validator merupakan Dosen Prodi Pendidikan Matematika IKIP PGRI Pontianak dan Guru matematika. Sedangkan subjek Ujicoba dalam penelitian ini adalah guru matematika dan siswa kelas IX SMPN 2 Nanga Taman. Guru sebagai fasilitator dalam proses pembelajaran dan siswa sebagai subjek utama dalam pelaksanaan uji coba perangkat pembalajaran.

\subsection{Prosedur Penelitian}

Penelitian dilakukan pada tanggal 1 Desember 2019 samapai 5 Desember 2019 di SMP Negeri 2 Nanga Taman. Subjek pengembangan dalam penelitian ini adalah Dosen IKIP PGRI Pontianak dan Guru matematika. Sedangkan subjek uji coba adalah 1 orang guru matematika SMP Negeri 2 Nanga Taman dan siswa kelas IX SMP Negeri 2 Nanga Taman berjumlah 20 siswa. Penelitian pengembangan ini menggunakan model pengembangan 4- $D$, adapun tahapan penelitian ini adalah define, design, development, dan dissemination. Tahapan pendefinisian terdiri dari : a) anaisis awal-akhir; b) anaisis siswa; c) analisis konsep; d) analisis tugas; d) analisis tugas; e) perumusan tujuan pembelajaran. Tahap perancangan terdiri dari: a) perancanga RPP; b) perancangan LKS; c) perancangan instrument dan validasi penilaian instumen penelitian perangkat pembelajaran. Perancangan RPP didasarkan prosedur pengembangan RPP yang telah diatur dalam Permendiknas Nomor 41 tahun 2007. Sedangkan untuk LKS dirancang melaluai beberapa tahapan yaitu: a) penyusunan peta kebutuhan bahan ajar; b) penentuan judul LKS; c) penulisan LKS; d) menentukan bentuk penilaian; e) menyusun 
materi. Selain itu, LKS juga dirancang berdasarkan aspek kelayakan isi, bahasa, penyajian dan graika seperti yang telah diatur dalam Permendikbud No. 71 tahun 2013. Pada tahapan pengembangan dilakukan: a) validasi perangkat pembelajaran oleh ahli materi, ahli media, dan guru matematika; b) uji coba; c) observasi keterlaksanaan pembelajaran; d) tes evaluasi hasil belajar; e) pengisian angket respon guru dan siswa.

Pada tahap define dan desigen diperoleh perangkat pembelajararan awal, kemudian tahap selanjutnya adalah development, perangkat pembelajaran awal akan divalidasi oleh 2 orang dosen (ahli) dan seorang guru matematika. Pada tahapan ini data diperoleh melalui lembar validator untuk mengatahui kevalidan perangkata pembelajaran yang telah dibuat. Setelah perangkat pembelajaran dinyatakan valid, perangkat pembelajaran akan di uji coba di SMP Negeri 2 Nanga Taman. Dalan uji coba data yang diperoleh berupa pernialian observasi keterlaksanaan pembelajaran dan hasil tes evaluasi hasil belajar siswa, data tersebut digunakan untuk mengetahui keefektifan pernagkat pembelajaran. Sedangkan data untuk menentukan kepraktiasan perangkat pembelajaran yaitu angket respon siswa dan angkaet respon guru.

\subsection{Instrumen Penelitan}

Instrumen yang digunakan untuk memperoleh, mengelola, dan menganalisis data adalah lembar validasi, lembar observasi keterlaksanaan pembelajaran, angket respon guru, angket respon siswa, dan sosl tes evaluasi hasil belajar. Perangkat pembelajaran yang dikembangkan harus memenuhi kriteria kualitas perangkat yang baik meliputi kriteria kevalidan, kepraktisan, dan keefektifan.

\subsection{Teknik Analisis Data}

Teknik analisis data pada penelitian ini adalah sebagai berikut.

\section{Analisis Kevalidan}

Instrumen yang digunakan untuk menganalisis kevalidan adalah penilaian perangkat pembelajaran untuk ahli materi, ahli media, dan guru matematika. Analisis kevalidan dilakukan dengan langkah-langkah sebagai berikut.

a. Melakukan tabulasi data dari validator.

b. Menghitung rata-rata jumlah skor yang diperoleh dengan rumus.

$$
\begin{aligned}
& \text { dengan } \quad \bar{x}=\frac{\sum x}{n} \\
& \bar{x}=\text { rata-rata perolehan skor, } \\
& \sum x=\text { jumlah skor yang diperoleh, } \\
& n=\text { banyak validator. }
\end{aligned}
$$

Kemudian dari rata-rata skor di atas diubah menjadi kriteria kualitatif berdasarkan pada Tabel 1 berikut (Widoyoko, 2017: 238).

Tabel 1. Konversi Data Kuantitatif ke Data Kualitatif

\begin{tabular}{ccc}
\hline No. & Rentang skor & Kriteria \\
\hline 1 & $\bar{x}>\mathrm{M}_{\mathrm{i}}+1,8 \mathrm{SB}_{\mathrm{i}}$ & Sangat Valid \\
2 & $\mathrm{M}_{\mathrm{i}}+0,6 \mathrm{SB}_{\mathrm{i}}<\bar{x} \leq \mathrm{M}_{\mathrm{i}}+1,8 \mathrm{SB}_{\mathrm{i}}$ & Valid \\
3 & $\mathrm{M}_{\mathrm{i}}-0,6 \mathrm{SB}_{\mathrm{i}}<\bar{x} \leq \mathrm{M}_{\mathrm{i}}+0,6 \mathrm{SB}_{\mathrm{i}}$ & Cukup Valid \\
4 & $\mathrm{M}_{\mathrm{i}}-1,8 \mathrm{SB}_{\mathrm{i}}<\bar{x} \leq \mathrm{M}_{\mathrm{i}}-0,6 \mathrm{SB}_{\mathrm{i}}$ & Kurang Valid \\
5 & $\bar{x} \leq \mathrm{M}_{\mathrm{i}}-1,8 \mathrm{SB}_{\mathrm{i}}$ & Sangat Tidak Valid \\
\hline
\end{tabular}


Keterangan:

$\bar{x} \quad=$ rata-rata perolehan skor

$\mathrm{M}_{\mathrm{i}}=\frac{1}{2}($ total skor maksimum ideal + total skor minimum ideal)

$\mathrm{SB}_{\mathrm{i}}=\frac{1}{6}($ total skor maksimum ideal - total skor minimum ideal)

$\mathrm{M}_{\mathrm{i}}=$ rata-rata ideal

$\mathrm{SB}_{\mathrm{i}}=$ simpangan baku ideal

Total skor maksimum ideal $=$ skor tertinggi $(5) \times$ jumlah butir

Total skor minimum ideal $=$ skor terendah $(1) \times$ jumlah butir

c. Berdasarkan perhitungan dalam tabel kriteria kevalidan perangkat pembelajaran, maka didapat interval kriteria kevalidan perangkat pembelajaran (RPP dan LKS) sebagai berikut.

Tabel 2. Interval LKS dan RPP

\begin{tabular}{cccc}
\hline \multirow{2}{*}{ No. } & \multicolumn{2}{c}{ Interval } & \multirow{2}{*}{ Kriteria } \\
\cline { 2 - 3 } & RPP & $\bar{x}>268,80$ & Sangat Valid \\
\hline 1 & $\bar{x}>172,20$ & $217,60<\bar{x} \leq 268,80$ & Valid \\
2 & $139,40<\bar{x} \leq 172,20$ & Cukup Valid \\
3 & $106,60<\bar{x} \leq 139,60$ & $166,40<\bar{x} \leq 217,60$ & Kurang Valid \\
4 & $73,80<\bar{x} \leq 106,60$ & $115,20<\bar{x} \leq 166,40$ & Sangat Kurang Valid \\
5 & $\bar{x} \leq 73,80$ & $\bar{x} \leq 115,20$ & \\
\hline
\end{tabular}

\section{Analisis Kepraktisan}

Instrumen yang digunakan untuk menganalisis kepraktisan adalah angket respon siswa. Analisis kepraktisan dilakukan dengan langkah-langkah yang sama dengan analisis kevalidan diatas dengan interval kriteria angket respon siswa dan guru sebagai berikut.

Tabel 3. Interval Kriteria Angket Respon Siswa dan Guru

\begin{tabular}{ccc}
\hline No & Interval & Kriteria \\
\hline 1 & $\bar{x}>84,00$ & Sangat Praktis \\
2 & $68,00<\bar{x} \leq 84,00$ & Praktis \\
3 & $52,00<\bar{x} \leq 68,00$ & Cukup \\
4 & $36,00<\bar{x} \leq 52,00$ & Kurang Praktis \\
5 & $\bar{x} \leq 36,00$ & Sangat Kurang Praktis \\
\hline
\end{tabular}

\section{Analisis Keefektifan}

\section{Analisis Observasi Keterlaksanaan Pembelajaran}

a. Menghitung banyaknya observer memilih pilihan "ya" pada aspek yang diamati dalam lembar observasi keterlaksanaan pembelajaran untuk tiap pertemuan.

b. Menghitung persentase jumlah yang didapat pada langkah sebelumnya menggunakan rumus sebagai berikut.

$$
\text { Persentase }(p)=\frac{\text { banyak jawaban "ya" }}{\text { banyak aspek yang diamati }} \times 100 \%
$$

c. Membandingkan persentase yang didapat dengan kriteria penilaian keterlaksanaan pembelajaran. Kriteria penilaian keterlaksanaan pembelajaran disajikan pada Tabel 4 (Purwanto, 2004: 82). 
Tabel 4. Interval Kriteria Keterlaksanaan Pembelajaran

\begin{tabular}{ccc}
\hline No & Rentang skor & Kriteria \\
\hline 1 & $90 \%<\bar{x} \leq 100 \%$ & Sangat Baik \\
2 & $80<\bar{x} \leq 90 \%$ & Baik \\
3 & $65<\bar{x} \leq 80$ & Cukup \\
4 & $55<\bar{x} \leq 65$ & Kurang \\
5 & $\bar{x} \leq 55$ & Sangat Kurang \\
\hline
\end{tabular}

\section{Analisis Tes Evaluasi Hasil Belajar}

Instrumen yang digunakan untuk menganalisis keefektifan penggunaaan perangkat pembelajaran ini adalah tes evaluasi hasil belajar. Nilai maksimal dalam tes evaluasi hasil belajar ini adalah 100 dengan KKM 65. Analisis keefektifan dilakukan dengan langkah-langkah sebagai berikut.

a. Melakukan tabulasi tes hasil belajar siswa.

b. Menghitung persentase ketuntasan tes evaluasi hasil belajar siswa.

$$
\text { Persentase ketuntasan }(x)=\frac{\text { jumlah siswa yang tuntas }}{\text { jumlah siswa }} \times 100 \%
$$

c. Kemudian persentase ketuntasan tes hasil belajar siswa dicocokkan dengan interval kriteria ketuntasan hasil tes evaluasi hasil belajar siswa sebagai berikut (Purwanto, 2004: 82).

\begin{tabular}{ccc} 
Tabel 5. Interval Kriteria Ketuntasan Hasil Belajar \\
\cline { 2 - 3 } No. & Rentang Skor & Kriteria \\
\hline 1 & $90 \%<\bar{x} \leq 100 \%$ & Sangat Baik \\
2 & $80<\bar{x} \leq 90 \%$ & Baik \\
3 & $65<\bar{x} \leq 80$ & Cukup \\
4 & $55<\bar{x} \leq 65$ & Kurang \\
5 & $\bar{x} \leq 55$ & Sangat Kurang \\
\hline
\end{tabular}

\section{HASIL DAN PEMBAHASAN}

Penelitian pengembangan perangkat pembelajaran ini menghasilkan produk berupa perangkat pembelajaran yang meliputi RPP dan LKS tabung dengan pendekatan matematika realistik yang dikembangkan berdasarkan model pengembangan 4- $D$ dengan tahapan define, design, develop, dan disseminate (dalam penelitian ini hanya sampai pada tahapan develop karena keterbatasan waktu).

Pada tahap design didapat sebuah perangkat pembelahjaran berupa RPP dan LKS yang dikembangkan dengan pendekatan matematika realistik pada pokok bahasan tabung, berikut merupakan contoh hasil design pengembangan RPP dan LKS.

Pada Gambar 1 terlihat RPP yang dikembangkan menggunakan pendekatan matematika realistik, dimana kegiatan pembelajaran terdiri dari lima kegiatan yaitu: penggunaan konteks, matematisasi, interaktifitas, hasil konstruksi, dan keterkaitan. Pembelajara diawali dengan siswa diberi masalah dalam kehidupan sehari-hari yang terdapat dalam "konteks", kemudian siswa menyelesaikan masalah tersebut dalam kelompok kecil "matematisasi", selanjutnya siswa akan mempresentasikan hasil diskusi didepan kelas "interaktifitas", dan siswa akan dibimbing guru untuk membuat kesimpulan dari hasil diskusi "hasil konstruksi". Pada akhir kegiatan siswa diberikan kasus yang berkaitan dengan ilmu lain "keterkaitan". 


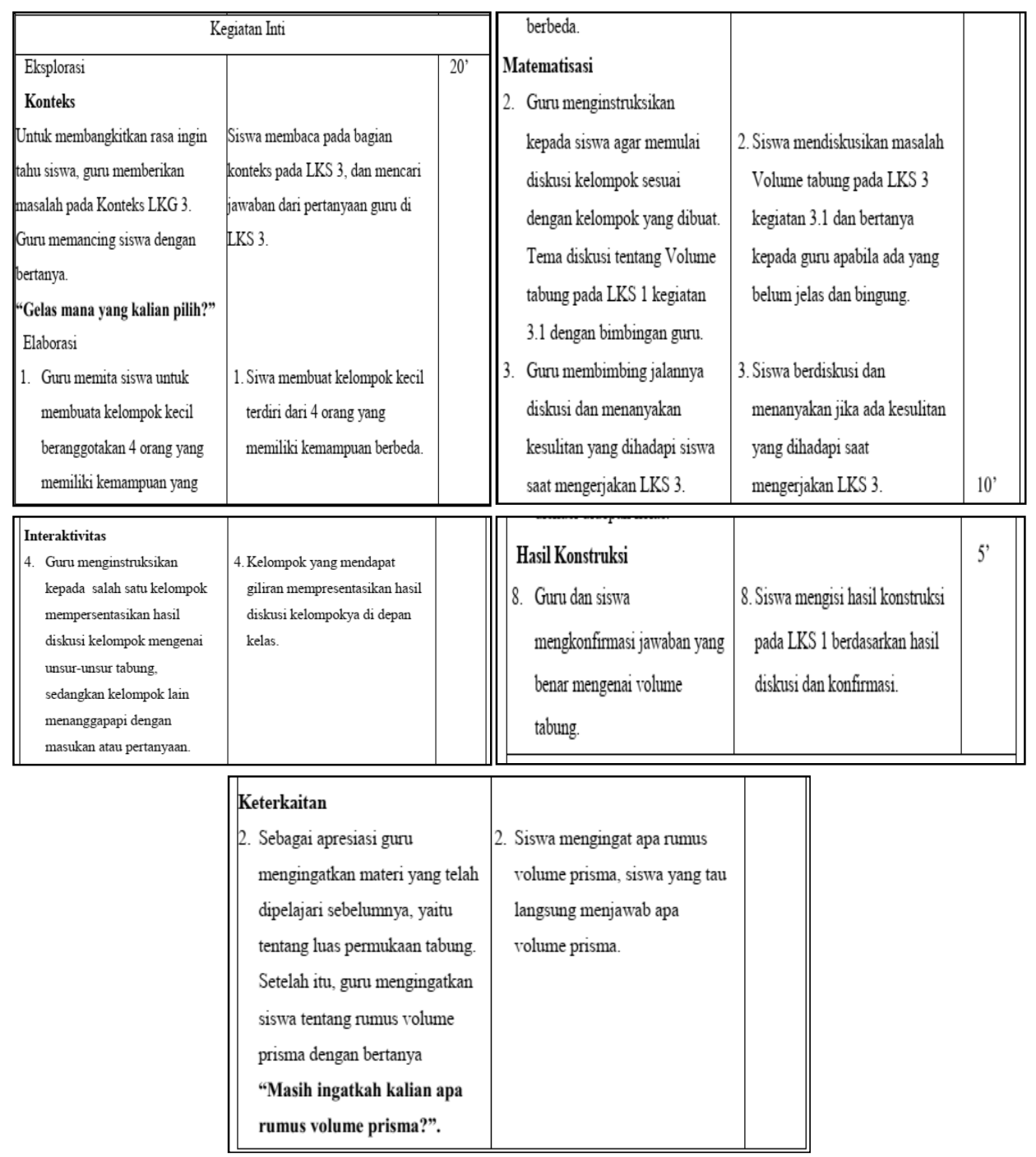

Gambar 1. Contoh RPP dengan Pendekatan Matematika Realistik pada sub Materi Volume Tabung.

Hasil design pengembangan LKS dengan pendekatan matematika realistik memiliki tahapan kegiatan pembelajaran yang sama dengan RPP, dimana LKS merupakan media pemelajaran yang digunakan oleh guru dalam proses belajar mengajar. Gambar 2 merupakan contoh LKS hasil design.

Perangkat pembelajaran berupa RPP yang dikembangkan telah dinilai oleh dua dosen ahli dan satu guru matematika, sedangkan LKS yang dikembangkan telah dinilai dua dosen ahli dan satu guru matematika. Berdasarkan hasil analisis penilaian kualitas RPP, diperoleh rata-rata total skor 190,33 dari total skor maksimum 205 dengan kriteria penilaian sangat valid. Hasil tersebut menunjukkan bahwa RPP dengan pendekatan matematika realistik yang dikembangkan telah sesuai dengan standar RPP menurut Lampiran Permendiknas Nomor 41 tahun 2007 tentang Standar Proses. Berdasarkan hasil analisis penilaian kualitas LKS oleh para ahli, diperoleh rata-rata total skor sebesar 297,5 dari total skor maksimum 320 dengan kriteria penilaian sangat valid. Hal tersebut manunjukkan bahwa LKS dengan pendekatan matematika realistik yang dikembangkan telah sesuai dengan kriteria LKS yang baik berdasarkan kriteria kelayakan buku teks atau bahan ajar menurut Pudji Mulyono. 

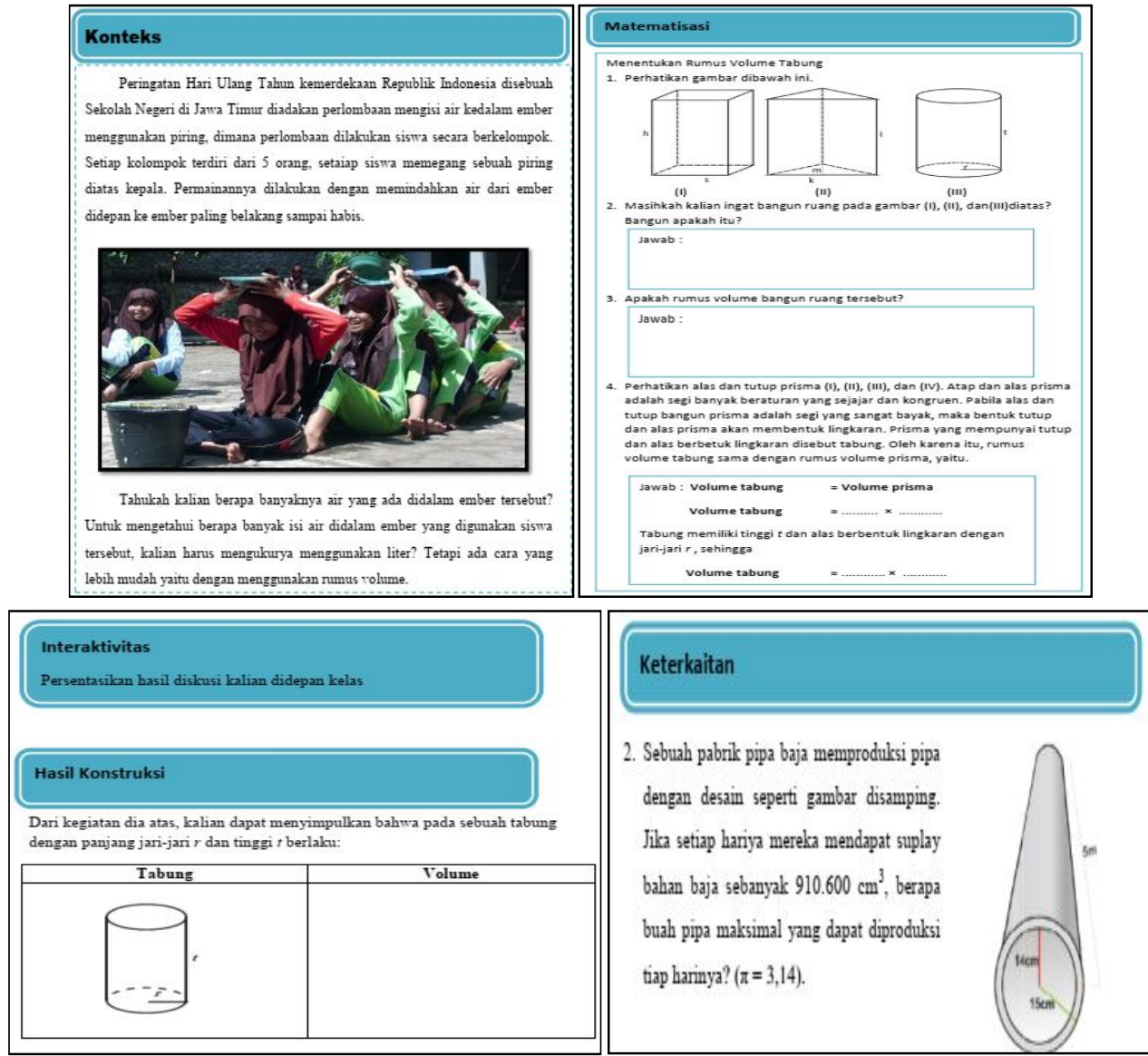

Gambar 2. Contoh LKS dengan Pendekatan Matematika Realistik pada Sub Materi Volume Tabung

Setelah dilakukan penilaian dan revisi terhadap perangkat pembelajaran, kemudian dilakukan uji coba perangkat pembelajaran di kelas IX SMP Negeri 2 Nanga Taman. Tahap uji coba diawali dengan pemberian apersepsi terkait materi yang akan dipelajari. Setelah itu, dilajutkan dengan pemberian konteks yang berisikan masalah relistik untuk membangkitkan rasa ingin tahu siswa. Siswa kemudian dibagi ke dalam kelompok kecil yang beranggotakan 4 siswa dengan tingkat kemampuan yang berbeda untuk menyelesaian kegiatan-kegiatan dalam LKS yang berisi matematisasi untuk dapat menyelesaian permasalahan pada konteks. Kegiatan selanjutnya, siswa berdiskusi dalam kolompok kecil ini merupakan kegiatan interaktivitas. Setelah selesai berdiskusi, kemudian salah satu kelompok mempresentasikan hasil diskusi kelompok di depan kelas (interaktivitas).

Siswa kemudian dibimbing oleh guru untuk mengkonfirmasi jawaban yang benar setelah kegiatan presentasi selesai. Setelah itu, siswa akan mengisi Hasil Konstruksi pada LKS sebagai bentuk aktivitas pemanfaatan hasil konstruksi siswa. Di akhir pertemuan siswa mengerjakan latihan soal pada pemecahan masalah dan keterkaitan.

Selama kegiatan uji coba berlangsung, salah satu guru yang diminta sebagai observer mengamati proses pembelajaran dan mengisi lembar observasi keterlaksanaan pembelajaran. Berdasarkan hasil analisis observasi keterlaksanaan pembelajaran diperoleh presentase rata-rata 94,87\% dengan kriteria sangat baik. Hasil tersebut menunjukkan bahwa perangkat pembelajaran yang dikembangkan efektif penggunaanya dalam kegiatan pembelajaran dan 
kegiatan pembelajaran dengan pendekatan matematika realistik telah terlaksana sesuai dengan rencana yang terdapat pada RPP. Meski telah mencapai kriteria sangat baik, peresentase keterlaksanaan pembelajaran pada pertemuan kedua dan ketiga dibandingkan dengan presentase pada pertemuan pertama masih rendah, yaitu 92,31\%. Hal tersebut diduga dikarenakan adanya diskusi kelompok yang kurang berjalan secara efektif ditinjau dari waktu pelaksanaannya.

Selain observasi keterlaksanaan pembelajaran, tes evaluasi belajar siswa juga digunakan untuk menentukan keefektifan perangkat pembelajaran. Siswa melakukan tes evaluasi belajar setelah uji coba perangkat pembelajaran. Berdasarkan analisis tes hasil belajar, diperoleh persentase ketuntasan sebesar 95\% dengan kriteria sangat baik. Hasil tersebut menunjukkan bahwa perangkat pembelajaran yang dikembangkan efektif untuk digunakan dalam pebelajaran.

Setelah melakukan tes evaluasi hasil belajar, siswa dan guru mengisi angket respon untuk mengetahui kepraktisan LKS yang dikembangkan. Berdasarkan hasil analisis angket respon, dapat disimpulkan bahwa LKS yang dibuat layak untuk digunakan oleh siswa dan guru untuk proses pembelajaran. Hal ini ditunjukkan oleh rata-rata total skor pada keempat aspek penilaian yakni kesesuaian materi dengan pendekatan pembelajaran matematika realistik, kelayakan bahasa, kelayakan penyajian, dan kelayakan grafika berturut-turut 91,1 dari skor maksimum 100 untuk angket respon siswa dengan kriteria sangat praktis dan 84 dari skor maksimum 100 untuk angket respon guru dengan kriteria sangat praktis. Meski kedua angket telah mencapai kriteria sangat praktis, tetapi pada angket respon guru masih ada yang hanya memiliki kriteria praktis. Berdasarkan uraian tersebut, dapat disimpulkan bahwa perangkat pembelajaran tabung dengan pendekatan matematika realistik yang dikembangkan memenuhi kriteria valid, praktis dan efektif.

\section{KESIMPULAN DAN SARAN}

Berdasarkan pada hasil penelitian dan pembahasan yang telah diuraikan pada bab sebelumnya, maka dapat disimpulkan sebagai berikut. (1) Pengembangan perangkat pembelajaran matematika dengan pendekatan matematika realistik pada pokok bahasan tabung untuk SMP Negeri 2 Nanga Taman kelas IX dikembangkan berdasarkan prosedur pengembangan $4 D$ yang dibatasi menjadi $3 D$ yang terdiri dari tahapan pendefinisian (define), perancangan (design), dan pengembangan (develop). (2) Berdasarkan pada hasil penilaian perangkat pembelajaran matematika oleh ahli dan guru matematika dapat disimpulkan bahwa perangkat pembelajaran yang dikembangkan memiliki kriteria sangat valid dengan rata-rata total skor 190,33 untuk RPP fan 297,5 untuk LKS. Berdasarkan pada hasil pengisisn angket respon siswa dan angket respon guru dapat disimpulkan bahwa perangkat pembelajaran yang dikembangkan memiliki kriteria sangat praktis dengan rata-rata total skor 91,1 untuk angket respon siswa dan 84 untuk angket respon guru. Berdasarkan pada hasil tes evaliasi hasil belajar siswa dan observasi keterlaksanaan pembelajaran dapat disimpulkan bahwa perangkat pembelajaran yang dikembangkan memiliki tingkat keefektifan yang baik dengan peresentase ketuntasan mencapai $95 \%$ dan rata-rata persentase observasi keterlaksanaan pembelajaran $94,87 \%$. 
Adapun saran yang dapat disampaikan dalam penelitian pengembangan ini adalah sebagai berikut.

1. Perangkat pembelajaran matematika (RPP dan LKS) yang dikembangkan dalam penelitian ini dari segi kevalidan, kepraktisan, dan keefektifan telah memenuhi kriteri yang baik sehingga dapat digunakan siswa ataupun guru dalam menunjang kegiatan pembelajaran tabung di kelas.

2. Perangkat pembelajaran matematika yang dikembangkan dalam penelitian ini masih terbatas pada satu materi pokok yaitu tabung, sehingga tidak menutup kemungkinan bagi peneliti lain utuk mengembangkan perangkat pembelajaran matematika dengan materei pokok yang lain. Selain itu perangkat pembelajaran yang dikembangkan dalam penelitian ini dapat digunakan sebagai bahan acuan dalam pengembangan perangkat pembelajaran matematika pada materi pokok lainnya.

\section{DAFTAR PUSTAKA}

Depdiknas. (2006). Peraturan Mentri Pendidikan Nasional Nomor 22 Tahun 2006 tentang Standar Isi Untuk Satuan Pendidikan Dasar dan Menengah, Jakarta: Depdiknas.

Depdiknas. (2008). Panduan Pengembangan Bahan Ajar. Jakarta. Depdiknas.

Depdiknas, (2010). Juknis Pengembangan Bahan Ajar SMA. Jakarta:Direktorat Pembinaaan SMA.

Harijanto, M. (2007). Pengembangan Perangkat Pembelajaran Untuk Peningkatan Kualitas Pembelajaran Program Pendidikan Pembelajaran Sekolah Dasar. Jurnal Didaktika. 2(1):216-226.

Marpaung, Y \& Julie, H. (2011). PMRI DAN PISA: Suatu Usaha Peningkatan Mutu Pendidikan Matematika di Indonesia. [Online]. http:/www.usd.acid/fakultas/pendidikan/ pen_matematika/f1 13/PMRI\%20dan\%20Pisa.pdf. [30 September 2017].

Muclich, M. (2007). KTSP (Kurikulum Tingkat Satuan Pendidikan) Dasar Pemahaman dan Pengembangan: Pedoman Bagi Pengelola Lembaga Pendidikan, Pengawasan Sekolah, Kepala Sekolah, Komite Sekolah, Dewan Sekolah, dan Guru. Jakarta. Bumi Aksara.

OECD. (2013). PISA 2012 Assessment and Analytical Framework: Mathemarics, Reading, Science, Problem Solving, and Financial Literacy. [Online].http://www.pisa.oecd.org. [3 September 2017].

OECD. (2017). PISA 2016 Assessment and Analytical Framework: Mathemarics, Reading, Science, Problem Solving, and Financial Literacy. [Online]. http://www.pisa.oecd.org. [30 September 2017].

Purwanto, N. M. (2004). Prinsip-prinsip dan Teknik Evaluasi Pengajaran. Bandung: PT Remaja Rosdakarya.

Sugihartono, dkk. (2007). Psikologi Pendidikan. Yogyakarta: UNY Press.

Sugiyono. (2012). Metode Penelitian Pendidikan Pendekatan Kualitatif, Kuantitatif, dan $R$ \& D. Bandung:Alfabeta $\mathrm{Cv}$.

Suhadi. (2007). Penyusunan Perangkat Pembelajaran dalam Kegiatan Lesson Study. Disajikan pada Pelatihan Lesson Study untuk Guru SMP Se-Kabupaten Hulu Sungai Utara tahun 2007. 
72 | Lusius Yupinus, Ichsan, Yadi Ardiawan - Pengembangan Perangkat Pembelajaran Matematika dengan Pendekatan Matematika ....

Suwaji, U. S. (2008). Permasalahan Pembelajaran Geometri Ruang dan Alaternatif Pemecahannya. Yogyakarta:PPPPTK Matematika.

Walle, J, A, Van de. (2006). The Van de Welle Professional Mathematics Teaching StudentCenter Mathematics. Bosto: Person Allyn and Bacon.

Widoyoko, E. P. S. (2017). Evaluasi Program Pembelajaran. Yogyakarta: Pustaka Pembelajaran.

Wijaya, Aryadi. (2012). Pendidikan Matematika Realistik: Suatu Alternatif Pendekatan Pembelajaran Matematika. Yogyakarta: Graha Ilmu. 